\title{
Intervention for Promoting Meaning in Life in Adolescents: Evaluation of the Process and Results
}

\author{
José Marcelo Oliveira da Luz ${ }^{1}$ \\ Programa de Pós-Graduação em Psicologia Clínica e Cultura, Universidade de Brasília, \\ Brasília, DF, Brazil \\ Secretaria Nacional de Juventude, Secretaria de Governo da Presidência da República, \\ Brasília, DF, Brazil \\ Sheila Giardini Murta \\ Departamento de Psicologia Clínica, Universidade de Brasília, Brasília, DF, Brazil \\ Thiago Antonio Avellar de Aquino \\ Centro de Educação, Universidade Federal da Paraíba, João Pessoa, PB, Brazil
}

\begin{abstract}
The objective of this study was to evaluate the implementation process and achievements in an intervention to promote meaning of life among adolescents. The participants were 47 adolescents of both sexes, aged 15 and 17, not randomly allocated into two groups: experimental $(N=22)$ and control $(N=25)$. The process of evaluation included satisfaction measures, social validity, engagement and understanding of activities by the teenagers. They were also carried out pre and post tests ratings: the participants of the two groups responded initially to the instruments Questionnaire Sense of Life and Affect Scale Positive and Negative. After 6 weekly meetings, which aimed to promote the sense of life, both groups were subjected to retesting with the same instruments. The results suggested an increase in the perception of meaning of life and decreased negative affect, indicating evidence supporting the effectiveness of the intervention. Overall, there was a membership of teenagers to the intervention program, as well as a positive evaluation. The results indicated evidence supporting the efficacy of the intervention.
\end{abstract}

Keywords: Meaning in life, health promotion, adolescent health, clinical trial.

\section{Avaliação de Resultados e Processo de uma Intervenção para Promoção de Sentido da Vida em Adolescentes}

\section{Resumo}

O objetivo deste estudo foi avaliar o processo de implementação e os resultados alcançados em uma intervenção para promoção de sentido da vida entre adolescentes. Participaram da pesquisa 47 adolescentes de ambos os sexos, com idades entre 15 e 17 anos, distribuídos não randomicamente em dois grupos: experimental $(N=22)$ e controle $(N=25)$. A avaliação de processo incluiu medidas de satisfação, validade social, engajamento e compreensão das atividades por parte dos adolescentes. Foram realizadas também avaliações de pré e pós testes: os participantes dos dois grupos responderam inicialmente aos instrumentos Questionário Sentido de Vida e Escala de Afetos Positivos e Negativos. Após 6 encontros semanais, que objetivaram promover o sentido de vida, ambos os grupos foram submetidos a uma retestagem com os mesmos instrumentos. Os resultados sugeriram um aumento na percepção de sentido de

1 Mailing address: Condomínio Mansões Serranas, Lote 6, Chácara D’Ouro - Setor Habitacional Jardim Botânico (Lago Sul), Brasília, DF, Brazil 71680-381. Phone: 61 96218774. E-mail: daluz@unb.br 
vida; diminuição de afetos negativos e a existência de planos futuros específicos, indicando evidências favoráveis à eficácia da intervenção. De forma geral, constatou-se uma adesão dos adolescentes ao programa de intervenção, bem como uma avaliação positiva do mesmo. Os resultados indicaram evidências favoráveis à eficácia da intervenção.

Palavras-chave: Sentido da vida, promoção da saúde, saúde do adolescente, estudo de intervenção.

\section{Evaluación de los Resultados y el Proceso de una Intervención para Promoción del Sentido de la Vida en Adolescentes}

\section{Resumen}

El objetivo del estudio fue evaluar el proceso de implementación y los resultados obtenidos, en una intervención para la promoción del sentido de la vida en adolescentes. En este estudio, participaron 47 adolescentes de ambos sexos, con edades entre los 15 y 17 años, distribuídos no randomicamente en dos grupos: experimental ( $n=22)$ y control $(n=25)$. La evaluación del proceso incluyó medidas de satisfacción, validez social, adhesión y comprensión de las actividades por parte de los adolescentes. También se realizaron evaluaciones pre y post-tests: los participantes de ambos grupos respondieron inicialmente al Cuestionario de Sentido de la vida y a la Escala de Afectos Positivos y Negativos. Después de 6 reuniones semanales, destinadas a promover el sentido de la vida, ambos grupos fueron evaluados con los mismos instrumentos. Los resultados sugieren un incremento en la percepción del sentido de la vida y una reducción del afecto negativo, proporcionando evidencia favorable a la eficacia de la intervención. En general, se observó una adecuada adhesión de los adolescentes al programa de intervención, así como una evaluación positiva de la misma. Los hallazgos parecen indicar evidencias favorables de la eficacia de la intervención para la promoción del sentido de la vida en adolescentes.

Palabras clave: Sentido de la vida, promoción de la salud, salud del adolescente, ensayo clínico.

The interest of psychology in investigations into meaning in life became especially accentuated after World War II with Viktor Frankl, the Viennese psychiatrist that created a psychotherapeutic school called logotherapy. Frankl (1946/2011) understood that experiential (to love people and contemplate nature and artistic works), creative (to create something for the world) and attitudinal values (to take positions in unchangeable situations of suffering) guide the existence of human beings and provide direction in life. Nevertheless, the current society increasingly frustrates the search for meaning, with it fulfilling many human needs, except the need for meaning (Frankl, 1978/2005).

For the author in question, the search for meaning in life is comprehended as a primary motivation of the individual and, in general, the indicators of the existential realization are presented as predictors of psychological well-being and of quality of life (Damásio, Melo, \& Silva, 2013). Authors such as Steger, Frazier, Oishi, and Kaler (2006) distinguish the search and the presence of meaning as independent factors. The first construct refers to feeling that life needs a meaning while the second refers to the perception of life full of personal meaning. Frankl, in turn, emphasizes that the frustration of the sense of meaning can result in a feeling of existential emptiness (Aquino, 2013; Frankl, 1946/2011), which is characterized as a lack of meaning in life, that is, the perception that the existence lacks a purpose.

The existential vacuum manifests itself mainly through boredom (Frankl, 1946/2011), which misdirects the lives of the individuals, putting them in a situation where they do not know what they want or what to do. Thus, the person starts to live in a provisional way and may succumb to conformism (wanting to do what others 
do) or totalitarianism (wanting to do what others want you to do), phenomena that are most frequent in adolescence (Frankl, 1946/2011, $1981 / 1990)$, a stage of the life cycle that coincides with the consolidation of the emotional and cognitive development of the individual and the construction of identity (Duarte, 2015).

With regard to this phase of development, Brazil has approximately 10.3 million young adolescents aged between 15 and 17 years, according to the National Youth Secretariat SNJ (2014). A considerable part of this great number of young people is more vulnerable to the existential vacuum. A study by Malta et al. (2011) found that among adolescent students in the $9^{\text {th }}$ year, $71.4 \%$ had tried alcohol at least once, $27.3 \%$ were regular alcohol users and approximately $8.7 \%$ had tried other drugs. Data obtained by Nascimento and Avallone (2013) in a study with adolescent students from the $9^{\text {th }}$ grade of elementary education to the $3^{\text {rd }}$ year of high school highlight a similar scenario. These data revealed that $27 \%$ of the adolescents were abusively using psychoactive substances and 5\% were dependent. The suicide rate in the Brazilian youth population reaches 5.6 per 100,000 inhabitants, according to data from Waiselfisz (2014). It is understood that these phenomena can be symptoms of a lack of direction or meaning in life (Frankl, 1978/2005).

The relationship between meaning in life, well-being and satisfaction with life has constituted the object of study in several investigations in Psychological Science (Aquino et al., 2015; Damásio, 2013; Gomes, 2009; Leonardi, 2011; Reinhold, 2004; Steger, 2009). Furthermore, studies have shown positive correlations between meaning in life and life satisfaction in adults between 22 and 60 years of age (Bonebright, Clay, \& Ankenmann, 2000) and between the presence of meaning and subjective wellbeing in adults aged 18 to 88 years (Debats, Van der Lubbe \& Vezeman, 1993; Doğana, Sapmaz, Telb, Sapmaz, \& Temizel, 2012). Among adolescents, studies indicate meaning in life to be a protective factor for health risk behaviors (Brassai, Piko, \& Steger, 2010, 2012).
The use of logotherapy for the prevention of an existential vacuum and for the promotion of meaning in life began with the creation of counseling centers for youths, devised by Frankl, in order to reduce the number of suicides among young people in Central Europe (Aquino, Damásio, \& Silva, 2012). From the perspective of logotherapy, this prevention aims to awaken and expand the healthy resources of the person to more adequately address the contingencies of life. A necessary condition to mobilize these resources would be a perception of a meaning, considering that having a meaning in life corresponds to a health protection factor (Frankl, 1946/2011; Lukas, 1992).

From this perspective, Aquino, Silva, Figueiredo, Dourado, and Farias (2011) developed and evaluated a proposal for the prevention of an existential vacuum with 33 adolescents from a public school in Campina Grande, Paraiba. In a quasi-experimental study, an intervention of 15 meetings was offered to the participants in the experimental group. The participants in the experimental and control groups underwent pre- and post-intervention evaluations, through the Purpose in Life Test of Crumbaugh and Maholich (1964), adapted and validated to the Brazilian population by Aquino et al. (2009). This instrument evaluates the degree of existential emptiness, existential despair, and the level of achievement of meaning in life.

The outcomes suggested an increase in the existential level of achievement and a decrease in levels of despair and existential emptiness among the participants in the experimental group. For the existential realization factor, there was a significant increase in the means of both the experimental group and the control group. The two groups, therefore, increased the sense of meaning in life. The change observed in the control group may have been the result of a closer relationship between the participants of the two groups, experimental and control, since, attending the same class, they shared common meeting spaces throughout the performance of the research. This fact indicated the need for 
further studies that control the diffusion between treatments (Kazdin, 2010) to obtain clearer conclusions.

The outcomes obtained by Aquino et al. (2011) can be added to other international interventions focused on promoting meaning in life for adolescents, even though low in number, that have achieved positive outcomes, associated with an improvement in the quality of life of adolescents (Haditabar, Far, \& Amani, 2013) and with an increase in psychological well-being in patients with cancer (Kang et al., 2009). Studies of interventions to promote meaning in life in adolescents are also scarce in the national literature. In addition to the proposal of Aquino et al. (2011), only studies in adult populations were found, with positive outcomes for the promotion of autonomy and increased quality of life in psychotic patients (Leonardi, 2011) and prevention of burnout in teachers (Reinhold, 2004). There are few national studies directed toward the promotion of meaning in life in the early stages of the life cycle in non-clinical populations. Thus, new studies to assess the intervention made by Aquino et al. (2011), as well as to develop other programs with a similar purpose, could expand the available evidence regarding the benefits of this type of intervention.

Taking into account the above considerations, the aim of this study was to replicate the intervention for the prevention of an existential vacuum and promotion of meaning in life for adolescents proposed by Aquino et al. (2011), expanding its evaluation, focusing on its implementation process and outcomes. The junction between evaluations of process and outcomes can offer a broader overview of the implementation and effects of a given intervention, as well as pre- and post-intervention evaluations, also called "black box" evaluations (Steckler \& Linnan, 2002). The evaluation process, of a strongly (although not exclusively) qualitative nature, allows us to understand how the intervention was conducted and received by the participants, sheds light on dimensions to be improved in later implementations of the program and facilitates the interpretation of the outcomes (Berkel, Mauricio, Schoenfelder, \& Sandler, 2011), when these are also evaluated. The specific aim of this study related to the evaluation of outcomes was to compare the pre- and post-intervention meaning of life and positive and negative affect scores between adolescent participants and non-participants of the intervention. Regarding the evaluation process, it was sought to: (a) evaluate the comprehension of the proposed activities and the engagement of the adolescents in these; (b) verify the significance attributed by the adolescents to the intervention and the importance of this in their everyday life, and (c) describe the satisfaction of the adolescents in relation to the intervention.

\section{Method}

\section{Participants}

Initially 102 adolescents of both genders, aged between 15 and 17 years, were invited to participate in the study. The participants were recruited in a non-profit institution, in the Federal District (BR), which provides social assistance services for children, adolescents, youths and their families. All the adolescents were inserted into the Service of Socio-Professional Education and Promotion of Productive Inclusion for Youths from 14 to 24 years, a program run by the institution, the general aims of which are training and preparation for the world of work for young people in situations of risk and social vulnerability.

The adolescents were distributed into the experimental (EG) and control (CG) groups by convenience, that is, by belonging to the same class and being available to participate in the intervention. The allocation into the groups was, therefore, not random, using a quasi-experimental design (Kazdin, 2010), with quantitative and qualitative measures. During the intervention there was no contact between the participants of the experimental and control groups, as each group attended the institution once a week, on different days. For the final sample, only the data of the participants who responded to the pre- and post-intervention evaluations were considered, totaling 25 adolescents in the CG and 22 adolescents in the EG. The EG was composed of 11 
of the Process and Results.

male and 11 female adolescents, aged 15 to 17 , while the CG consisted of 12 male and 13 female adolescents, aged between 16 and 17 years.

\section{Instruments}

Sociodemographic Evaluation Questionnaire. Consisting of 25 closed questions used to collect data on the gender, age, affiliation, housing conditions, consumer goods, social class and social support network of the participants.

Meaning in Life Questionnaire. Instrument originally proposed by Steger et al. (2006) and validated in Brazil by Damásio (2013), composed of 10 items that aim to evaluate the indices of the search for and the presence of meaning in life, answered on a scale of 1 (completely false) to 7 (completely true). The validation of this instrument for Brazil took place with a population of 3,020 participants, aged between 18 and 91 years, in 22 Brazilian states, and showed that both scales - presence of meaning (I understand the meaning of my life) and search for meaning (I am looking for meaning in my life) - presented excellent psychometric properties, with Cronbach's alpha ()$=.88$ and ()$=.85$, respectively.

Positive and Negative Affect Scale. Instrument originally developed by Diener and Emmons (1984) to evaluate the valence of the emotions formed by nine adjectives, four positive (happy, cheerful, satisfied and entertained) and five negative (depressed, worried, frustrated, angry and unhappy). It was validated in Brazil by Chaves (2003) who, in order to balance the number of adjectives for both types of emotions, added an adjective for positive affect: optimistic. The scale of 10 items, answered on a seven-point scale ranging from 1 (nothing) to 7 (extremely), was validated in a sample of 306 participants from the city of João Pessoa-PB, aged from 18 to 84 years. The reliability coefficients were .81 and .78 for the positive and negative affects, respectively (Chaves, 2003).

Letter to a Friend. A blank sheet was used on which the adolescents were asked to write a letter to an imaginary friend, after creative visualization. The adolescents were asked to project their lives 20 years into the future, imagining what could have happened in the interval. Soon after, they were asked to write a letter to a friend who they had not had contact with throughout this period of life, telling him how they were at that time and what had happened in their lives. The aim of this instrument was to evaluate the future prospects of the adolescents, through the presence of dreams or dreams and goals achieved, seen as indicators of future plans and life projects.

Field Diary. This consisted of a notebook in which the researcher recorded the statements of the participants considered significant, as well as their perceptions of the group process. The diary was used to record the procedures performed in each session and to evaluate the comprehension of the proposed activities and the engagement of the participants. It also served to support the methodological adjustments during the intervention.

Tree of My Life. This was developed by the authors in order to evaluate the social validity of the intervention, defined as the perception of relevance of the intervention procedures by the participants (Lane \& Beebe-Frankenberger, 2004). The participants were asked to fill in the blanks in the tree leaves with the contents of the intervention according to their significance in their lives.

Emotions Diary. This instrument was developed by the authors for this study, consisting of a table with 15 drawings of seven positive emotions, seven negative emotions and one unknown emotion, aiming to assess, at the end of each meeting, the satisfaction of the participants with regard to the intervention, from the report of emotions experienced in the session. In the construction of this instrument, the emotions were selected randomly and submitted to consultation with a group of adolescents and clinical psychologists to assess their clarity and relevance as possible indicators of satisfaction experienced in workshops for adolescents.

\section{Procedures}

Recruitment. The recruitment process of the participants was composed of six attempts, in different educational institutions for adolescents, of which only the last attempt was successful. Initially, the target audience of the study 
consisted of university students in their first year of university. The main difficulty highlighted by the university in accepting the study was the duration of the intervention, initially planned for 15 meetings. In view of this, it was decided to change the target audience and direct the intervention towards adolescents in high school, while simultaneously reducing the duration of the intervention. After its reduction to 11 sessions, the same difficulty was reported by four other institutions contacted. Finally, after further adjustment in the amount of sessions, considering the original content and reducing the number to six sessions, the program was offered to a sixth institution, which agreed to participate in the study.

Data Collection. The EG was offered an intervention in group format centered on reading poems, fables and parables from the general literature and reflections based on a dialogical relationship. The intervention was developed in six weekly meetings of 150 minutes each, totaling 15 hours, distributed over six weeks.

Table 1

Script of the Intervention for the Prevention of the Existential Vacuum

\begin{tabular}{|c|c|c|}
\hline Theme & Aim & Techniques \\
\hline $\begin{array}{l}\text { Session } 1 \\
\text { - The human spirit and } \\
\text { will dimension of meaning. }\end{array}$ & $\begin{array}{l}\text { Pre-intervention test; Reflect } \\
\text { on the specifically human } \\
\text { dimension, on the lifestyle } \\
\text { of the participants and on the } \\
\text { motivation of human beings } \\
\text { given their finite existence. }\end{array}$ & $\begin{array}{l}\text { - Presentation of the proposed intervention; } \\
\text { - Personal presentation technique; } \\
\text { - Application of the pre-test; } \\
\text { - Texts: "The eagle and the hen" and "A wise } \\
\text { man and an acrobat"; } \\
\text { - Emotions Diary. }\end{array}$ \\
\hline $\begin{array}{l}\text { Session } 2 \\
\text { - Freedom x responsibility } \\
\text { and Self-Transcendence. }\end{array}$ & $\begin{array}{l}\text { Reflect on the dimensions } \\
\text { of human existence: freedom } \\
\text { and responsibility and the } \\
\text { concept of self-transcendence } \\
\text { of Viktor Frankl. }\end{array}$ & $\begin{array}{l}\text { - Warm up; } \\
\text { - Texts: "The road not taken" and "The two } \\
\text { boys"; } \\
\text { - Technique "What am I doing? What can I do?"; } \\
\text { - Emotions Diary. }\end{array}$ \\
\hline $\begin{array}{l}\text { Session } 3 \\
\text { - Conformism } \\
\mathrm{x} \text { totalitarianism and } \\
\text { discovering our worth } \\
\text { as a human being }\end{array}$ & $\begin{array}{l}\text { Discussion of these two } \\
\text { symptoms of existential } \\
\text { vacuum that characterize the } \\
\text { current society and Increase } \\
\text { awareness about the value } \\
\text { of life and the dignity of the } \\
\text { human being. }\end{array}$ & $\begin{array}{l}\text { - Warm up; } \\
\text { - Texts: "The emperor's new clothes", } \\
\text { "The little boy and the red flower" } \\
\text { and "Assembly of the tools"; } \\
\text { - Technique: Quality and values; } \\
\text { - Emotions Diary. }\end{array}$ \\
\hline $\begin{array}{l}\text { Session } 4 \text { - Finding sense } \\
\text { in extreme situations } \\
\text { and say yes to life in spite } \\
\text { of everything. }\end{array}$ & $\begin{array}{l}\text { Reflect on the possibilities } \\
\text { of meaning in unchangeable } \\
\text { situations of life and the } \\
\text { postures and attitudes towards } \\
\text { the difficulties of life. }\end{array}$ & $\begin{array}{l}\text { - Warm up; } \\
\text { - Texts: "The two jewels" and "The mountain } \\
\text { climber"; } \\
\text { - Emotions Diary. }\end{array}$ \\
\hline $\begin{array}{l}\text { Session } 5 \\
\text { - The suppressed } \\
\text { and the discovery } \\
\text { of meaning }\end{array}$ & $\begin{array}{l}\text { Reflect on the } \\
\text { unconditionality of the } \\
\text { meaning of life. }\end{array}$ & $\begin{array}{l}\text { - Warm up; } \\
\text { - Texts: "Creator and creature" and "Everything } \\
\text { depends on me alone"; } \\
\text { - Technique: Jig-saw puzzle; } \\
\text { - Emotions Diary. }\end{array}$ \\
\hline $\begin{array}{l}\text { Session } 6 \text { - Life Project, } \\
\text { final evaluation } \\
\text { and post-test. }\end{array}$ & $\begin{array}{l}\text { Encourage participants } \\
\text { to construct their life } \\
\text { project, post-intervention } \\
\text { evaluation. }\end{array}$ & $\begin{array}{l}\text { - Warm up; } \\
\text { - Text: "The sculptor"; } \\
\text { - Techniques "Hour Glass", "Letter to a Friend", } \\
\text { - Emotions Diary; } \\
\text { - Tree of Life; } \\
\text { - Post-test application. }\end{array}$ \\
\hline
\end{tabular}


The EG was composed of two groups of adolescents, who participated in the intervention on different days of the week. In order to be sure that the groups received the same intervention and that this was true to the content of the original intervention (Aquino, 2015; Aquino et al., 2011), a previous script was elaborated with themes and techniques specific to each meeting. The script of the meetings is described fully in Aquino (2015) and summarized in Table 1.

Group dynamic techniques, body exercises for warming up and relaxation, creative visualization and Socratic dialogue were used. In general, the sessions were composed of activities in small group and individual activities. Initially, the adolescents were informed about the subject and objectives of the day and received the texts for reading or watching videos, with guiding questions for reflection. Next everyone shared their responses, with the researcher stimulating the establishment of a parallel with the moment that each person experienced. At the end of each session the participants were asked to rate their feelings and satisfaction with the session and encouraged to continue the reflection during the week. In order to make the intervention more attractive, some text reading activities were replaced by videos and animations, preserving the content of the proposed text.

Both groups, EG and CG, responded to the pre- and post-intervention measures and to the Sociodemographic Evaluation Questionnaire. In the EG, the application of the Meaning in Life Questionnaire and Positive and Negative Affect Scale was performed in the first and last sessions. In the last session for the EG the Letter to a Friend was also applied. During the intervention, qualitative measurements were performed. Towards the end of each meeting, the adolescents were asked to respond to the instruments Tree of My Life and Emotions Diary. Immediately after the end of each session, the researcher recorded the relevant events observed in the session of the day in the Field Diary.

Data Analysis. For the qualitative analysis, content analysis was used, in which categorization of the content recorded during the intervention followed the model proposed by Bardin
(1977). Initially, the data was read separately and repeatedly and the themes that stood out in the statements of the adolescents were highlighted; then these themes were reviewed and grouped into categories established by the researcher. A second researcher was consulted in order to establish the differentiation of the categories. Finally, the frequencies of these themes in the reports of the participants were quantified.

For the quantitative data, SPSS (version 18) was used. Descriptive statistics (mean and standard deviation) and the t-test for repeated measures were used in order to verify differences between the measurements of the presence of meaning, search for meaning, positive and negative affect in the pre- and post-test.

Ethical Considerations. The study was registered with the Human Sciences Research Ethics Committee of the University of Brasilia under No. 37157214.5.0000.5540. All the ethical guidelines of Resolution 466/12 of the National Health Council were adopted, including the provision of information to the participants and consent expressed through the signing of the consent form by the adolescents and their parents.

\section{Results}

\section{Sociodemographic Characterization}

Table 2 shows the socio-demographic characteristics of the sample. Among the data presented, attention is drawn to the high percentage of adolescents who did not participate in any collective youth activities, such as sports or student groups (EG 36.4\% and CG 40\%), with a mean participation in 1.0 group in the EG ( $S D$ $1.069)$ and 0.80 groups in the CG (SD 0.816). Regarding socioeconomic classification, the number of participants who were in the $\mathrm{B}$ and $\mathrm{A}$ classes was highlighted, according to the Brazil Classification Criteria 2015 of the Brazilian Association of (Market) Research Companies ABEP. Adopting only the criterion of per capita income of the ABEP, all the participants were in $\mathrm{D} / \mathrm{E}$ classes (per capita income below $\mathrm{R} \$$ 639.78). All the adolescents were participants of a socio-professional training program and were therefore preparing to enter the labor market. 
Table 2

Socio-Demographic Characteristics of the Sample according to the Experimental Group

\begin{tabular}{|c|c|c|}
\hline Variables & EG & $\mathrm{CG}$ \\
\hline \multicolumn{3}{|l|}{ Gender } \\
\hline Female & 11 & 13 \\
\hline Male & 11 & 12 \\
\hline \multicolumn{3}{|l|}{ Age } \\
\hline Mean & 15.86 & 16.64 \\
\hline Standard Deviation & 0.468 & 0.490 \\
\hline \multicolumn{3}{|l|}{ Participation in Youth Groups } \\
\hline \multicolumn{3}{|l|}{ Quant. Groups (\%) } \\
\hline None & $8(36.4 \%)$ & $10(40.0 \%)$ \\
\hline One & $9(40.9 \%)$ & $11(44.0 \%)$ \\
\hline Two & $3(13.6 \%)$ & $3(12.0 \%)$ \\
\hline Three & $1(4.5 \%)$ & $1(4.0 \%)$ \\
\hline Four & $1(4.5 \%)$ & - \\
\hline Mean & 1.00 & 0.80 \\
\hline Standard Deviation & 1.069 & 0.816 \\
\hline \multicolumn{3}{|l|}{ Type of Youth Group } \\
\hline Religious & 11 & 13 \\
\hline Sport & 7 & 4 \\
\hline Student & 2 & 2 \\
\hline Other & 1 & 1 \\
\hline \multicolumn{3}{|l|}{ Socioeconomic Class* } \\
\hline Class A & 2 & 1 \\
\hline Class B1 & 2 & 3 \\
\hline Class B2 & 11 & 10 \\
\hline Class C1 & 3 & 7 \\
\hline Class C2 & 4 & 3 \\
\hline Class D/E & - & - \\
\hline
\end{tabular}

Note. *Classification according to the questionnaire proposed by the Classification Criteria Brazil 2015, of the Brazilian Association of (Market) Research Companies - ABEP.

\section{Evaluation of the Outcomes}

Initially descriptive analysis of the preand post-intervention mean scores of the study variables was performed (presence of meaning, search for meaning, positive affect, negative affect) in the EG and CG. The $t$-test for repeated measures demonstrated a statistically significant change in the presence of meaning factor, an in- crease in the mean of this variable between the pre- and post-intervention in the EG $(p=.0001)$, while in the CG the increase was not significant. The means, standard deviations and statistical significance of the experimental and control groups are shown in Table 3 . The search for meaning factor presented no significant change in either group. 
Table 3

Comparison between the Experimental and Control Groups in the Pre- and Post-Test, according to the Presence of Meaning and Search for Meaning Variables

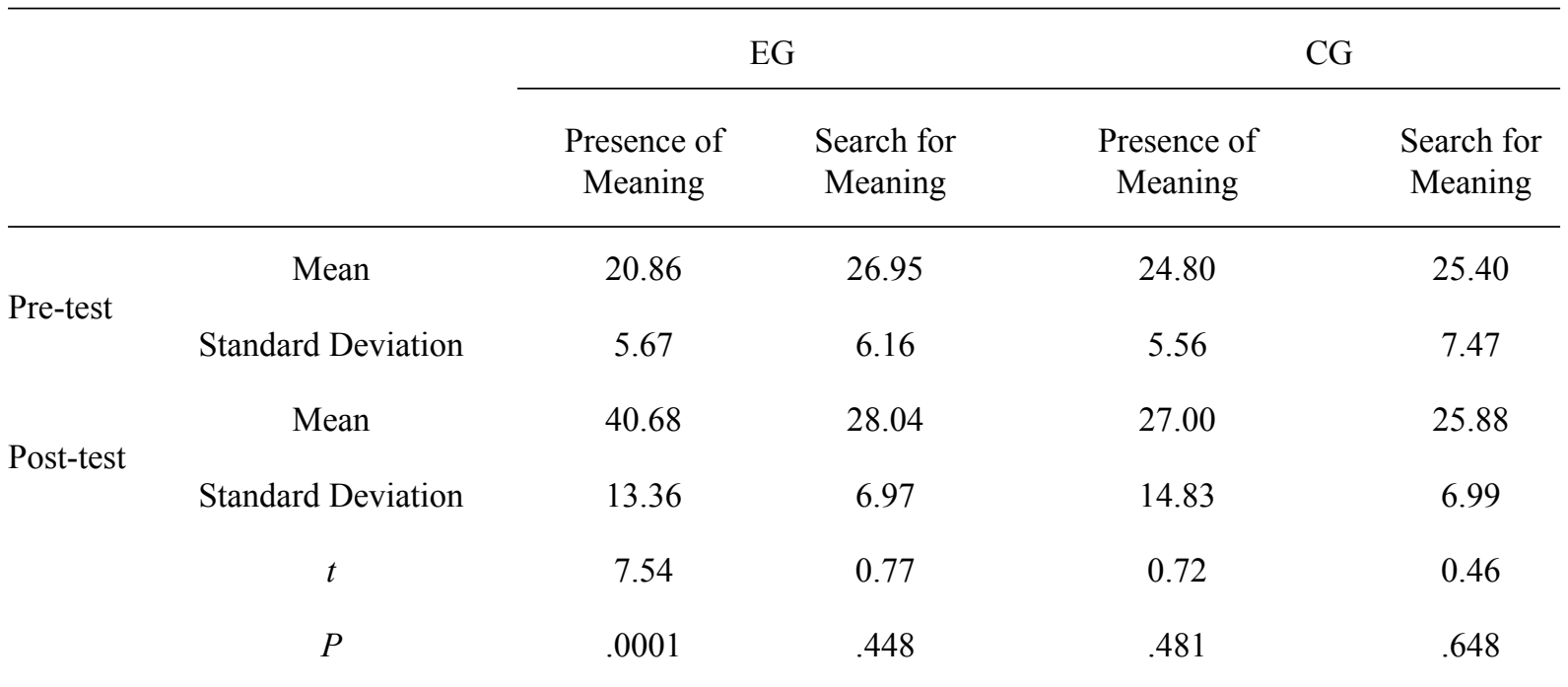

Table 4 presents the outcomes of the comparison between the EG and CG for the outcomes obtained through the Positive and Negative Affect Scale. The EG data showed a significant decrease $(p=.026)$ in the negative affect scores, between the pre- and post-intervention moments, whereas in the $\mathrm{CG}$ the change was not significant. A significant decrease $(p=.0001)$ in the indices of positive affect was also noticed in the CG.

Table 4

Comparison between the Experimental and Control Groups in the Pre- and Post-Test, according to the Positive Affects and Negative Affects Variables

\begin{tabular}{|c|c|c|c|c|c|}
\hline & & \multicolumn{2}{|c|}{ EG } & \multicolumn{2}{|c|}{ CG } \\
\hline & & $\begin{array}{l}\text { Positive } \\
\text { Affects }\end{array}$ & $\begin{array}{c}\text { Negative } \\
\text { Affects }\end{array}$ & $\begin{array}{l}\text { Positive } \\
\text { Affects }\end{array}$ & $\begin{array}{c}\text { Negative } \\
\text { Affects }\end{array}$ \\
\hline \multirow{2}{*}{ Pre-test } & Mean & 25.45 & 14.95 & 24.68 & 14.44 \\
\hline & Standard Deviation & 4.44 & 5.82 & 0.96 & 0.99 \\
\hline \multirow{4}{*}{ Post-test } & Mean & 26.73 & 11.64 & 13.64 & 13.64 \\
\hline & Standard Deviation & 5.01 & 3.66 & 0.63 & 0.63 \\
\hline & $T$ & 1.25 & 2.40 & 7.78 & 0.848 \\
\hline & $P$ & .226 & .026 & .0001 & .40548 \\
\hline
\end{tabular}

\section{Evaluation of the Process}

Regarding the comprehension of the procedures and the engagement of the participants in the proposed activities, some reports suggested that the adolescents understood and engaged positively in the intervention. This involvement went beyond the space of the group, which can be perceived from the words of one participant: "these activities make us think very much at home", "it makes you want to cry sometimes, 
when we remember these texts". This posture of involvement in the activity was also observed by the researcher in the behaviors of the adolescents in the group, especially in activities that, for their performance, required a cooperative attitude between the subjects.

The data obtained through the Letter to a Friend mostly highlighted the presence of future plans (77 reports, 98.8\%) compared to the absence of future plans (1 report, 1.2\%). Among the plans reported, specific plans (75 reports, $96.2 \%$ ) and non-specific plans (2 reports, $2.6 \%$ ) were identified. Specific plans mainly included career and family plans and investment in academic education. The definitions, examples and frequency of the categories and subcategories of the reports are shown in Table 5.

Table 5

Reports of the Participants that Indicate Future Plans

\begin{tabular}{|c|c|c|c|c|}
\hline & Category & Definition & $\begin{array}{l}\text { Frequency } \\
\qquad(\%)\end{array}$ & $\begin{array}{l}\text { Examples of Reports } \\
\text { on Future Plans }\end{array}$ \\
\hline \multirow{6}{*}{$\begin{array}{l}\text { Specific } \\
\text { plans }\end{array}$} & $\begin{array}{l}\text { Plans for } \\
\text { Personal Growth }\end{array}$ & $\begin{array}{l}\text { Developing positive } \\
\text { personal characteristics. }\end{array}$ & $5(6.4 \%)$ & $\begin{array}{l}\text { "She made me such a good person, } \\
\text { responsible, competent..." }\end{array}$ \\
\hline & Family Plans & $\begin{array}{l}\text { Construction and/or } \\
\text { strengthening of family } \\
\text { bonds. }\end{array}$ & $20(25.6 \%)$ & $\begin{array}{l}\text { "Ah, I got married two years ago! } \\
\text { I already have a one year old } \\
\text { daughter". }\end{array}$ \\
\hline & Academic Plans & $\begin{array}{l}\text { Investment in specific } \\
\text { academic training } \\
\text { or improvement of studies. }\end{array}$ & $13(16.7 \%)$ & $\begin{array}{l}\text { "... While I finished my architecture } \\
\text { and visual arts university course". }\end{array}$ \\
\hline & $\begin{array}{l}\text { Professionals } \\
\text { Plans }\end{array}$ & $\begin{array}{l}\text { Definition of a } \\
\text { professional } \\
\text { career to follow. }\end{array}$ & $22(28.2 \%)$ & $\begin{array}{l}\text { "I am a renowned architect, my } \\
\text { paintings are shown in hundreds of } \\
\text { exhibitions..." }\end{array}$ \\
\hline & Leisure Plans & $\begin{array}{l}\text { Realization of activities } \\
\text { and leisure practices. }\end{array}$ & $8(10.3 \%)$ & $\begin{array}{l}\text { "I go out almost every weekend } \\
\text { with my mom, we do shopping, have } \\
\text { lunch, have a lot of fun!" }\end{array}$ \\
\hline & Property Plans & $\begin{array}{l}\text { Planning procurement } \\
\text { of goods or construction } \\
\text { of property. }\end{array}$ & $7(9.0 \%)$ & "I made the house of my dreams". \\
\hline Subtotal & - & - & $75(96.2 \%)$ & - \\
\hline $\begin{array}{l}\text { Unspecific } \\
\text { Plans }\end{array}$ & - & $\begin{array}{l}\text { Indication that there was } \\
\text { a positive change, but without } \\
\text { specification of a specific } \\
\text { category. }\end{array}$ & $\begin{array}{c}2 \\
(2.6 \%)\end{array}$ & $\begin{array}{l}\text { I was able to achieve most of my } \\
\text { dreams. }\end{array}$ \\
\hline Subtotal & - & - & $2(2.6 \%)$ & - \\
\hline $\begin{array}{l}\text { Absent } \\
\text { Plans }\end{array}$ & - & $\begin{array}{l}\text { No indication } \\
\text { accomplishments } \\
\text { or goals achieved. }\end{array}$ & $(1.2 \%)$ & $\begin{array}{l}\text { "I'm fine, I miss my youth, thinking } \\
\text { of what I left behind. But I'm doing } \\
\text { new things in my day to day. That's } \\
\text { it, I miss that mess we made". }\end{array}$ \\
\hline Subtotal & - & - & $1(1.2 \%)$ & - \\
\hline
\end{tabular}

The reports of the participants from the Tree of My Life, which evaluated the contents that drew the attention of the participants and that were considered important for the life of each of them, suggests a recognition of the importance of the intervention and what lessons could be taken for the daily lives of the adolescents. Considering the words that were cited by at least 
two adolescents, the following frequencies were obtained: meaning (12), life (11), choices (9), dreams (7), focus (6), persistence (6), skills (5), will (5), creativity (4), motivation (4), attitudes (4), future (4), hope (4), strength (4), aims (4), self-confidence (4), responsibility (3), head (3), opinions (3), love (3), ideas (3), competence (2), effort (2), achievements (2), respect (2), groups (2), overcoming (2), attention (2), pathways (2), reflection (2), and doing (2).

The outcomes obtained through the Emotions Diary, aiming to assess the satisfaction of the participants, showed the emotions experienced by the participants at the end of each meeting. The most common emotions were positive, followed by negative, in the following order: happy (71), quiet (54), excited (42), satis- fied (39), thankful (33), hopeful (30), confident (29), concerned (14), anxious (13), confused (11), sad (9), bored (8), and frightened (4). The emotion "angry" was not mentioned, while there were 8 reports of unidentified emotions ("do not know"), when the teenager could not name the feeling perceived.

As described in Figure 1, there was a gradual increase in positive emotions during the intervention, a certain stability of negative emotions and a decrease in unidentified emotions. The small increase in negative emotions, observed in the final session, may be justified by the feeling of the participants faced with the end of the intervention, as suggested by the statement of one of the adolescents: “... I'm sad it's over. It passed so fast"'.

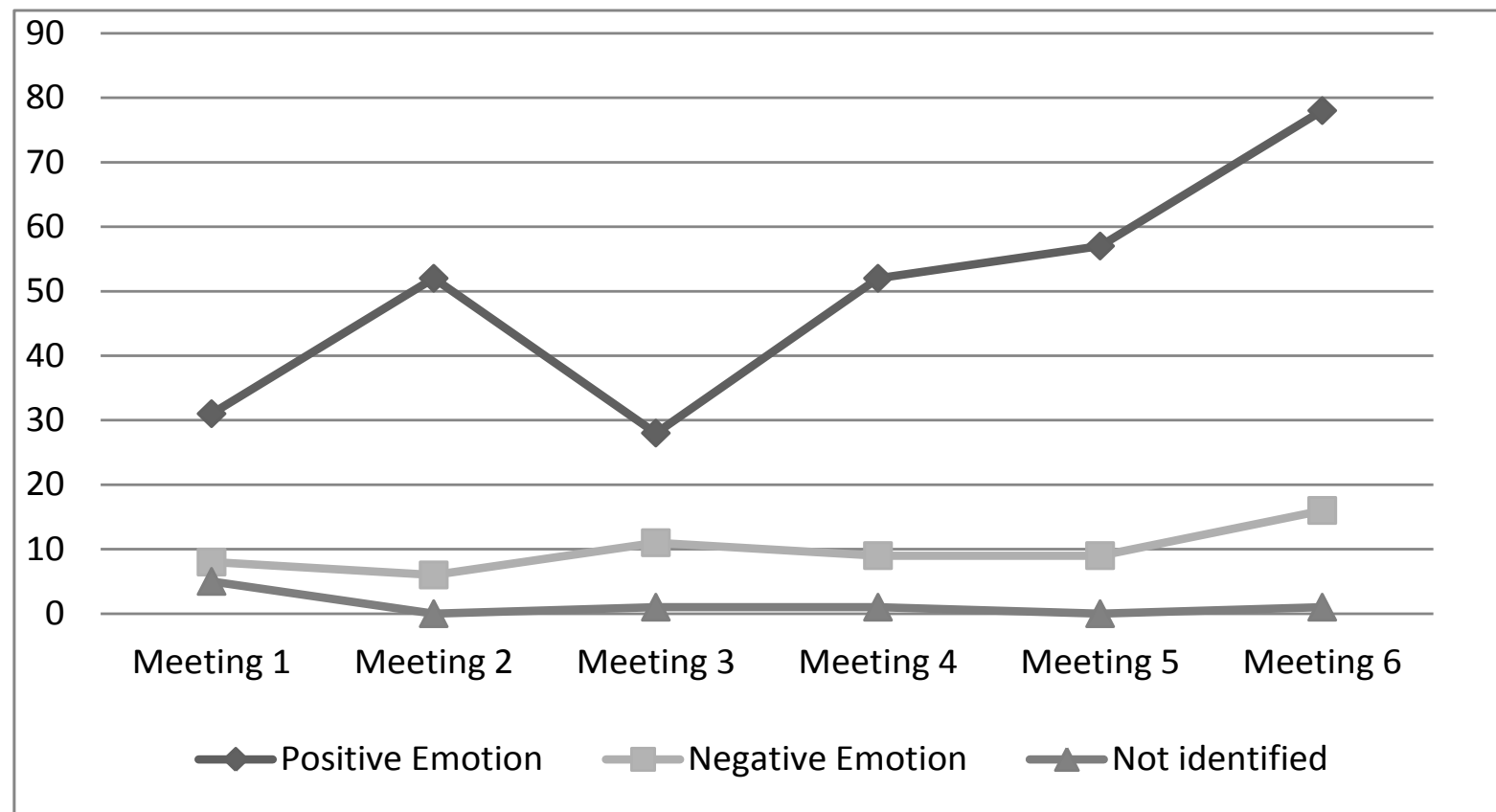

Figure 1. Distribution of reported emotions in the evaluation of satisfaction of the participants in each session.

\section{Discussion}

This study aimed to evaluate the outcomes and the implementation process of an intervention to promote meaning in life for adolescents. It was found that after the intervention the participants of the EG presented a significant change in the perception of meaning in their lives, compared to those of the CG. Similar outcomes were found by Aquino et al. (2011). According to Frankl (1946/2011), one of the strongest indicators of the presence of meaning is to have a defined purpose in life, a cause or person that is worth living for. This comprehension is shared by Ryff and Keyes (1995), who put the purpose of life as a component of psychological well-being. 
According to the authors in question, the purpose of life can be understood as the existence of aims in life, a sense of direction, significant goals and the feeling that life has a meaning. Frankl (1946/2011) says that an existential vacuum is characterized by the feeling that life is meaningless or without a definite purpose, limiting future possibilities. Thus, to promote the meaning of life is equivalent to mitigating this perception of emptiness in individuals, expanding their protective factors. In reference to the search for meaning factor, there was no significant change in either of the groups. Studies suggest, in general, negative correlations between the search for and presence of meaning (Damásio, 2013) and between the search for meaning and subjective well-being (Bonebright et al., 2000). Thus, no change in this variable should be interpreted as expected and positive.

Regarding the positive affect scores, the data revealed significant changes, represented by a decrease in negative affect in the EG and a decrease in positive affect in the CG. Furthermore, it was found that the mean of positive affects was higher than that of negative affects. This result is supported by previous studies (Arteche \& Bandeira, 2003; Huebner \& Dew, 1996), suggesting that, in general, adolescents report good levels of well-being. The political and economic context that the Brazil was going through when collecting data in February and March 2015, may be a possible explanation for the observed change in the $\mathrm{CG}$, since, unlike the participants of the EG, the participants of this group were not offered a space for listening and sharing feelings. The sample was recruited among adolescents who were entering the labor market and, therefore, it is possible that they felt negatively impacted by the economic climate. Considering this context, also experienced by the participants of the EG, the observed change can also be backed by Frankl when he says that the spiritual dimension in the human being preserves protective factors in individuals, regardless of the situation that they experience.

With regard to the process variables, the outcomes show a good comprehension by the adolescents of the proposed activities and an active participation in them. This understanding came from the observations of the researcher in the performance of the tasks and in the interactions among the adolescents during the intervention. Reports that indicate personal exposure of the adolescent support this understanding in relation to engagement in the tasks. When asked to imagine what they would do on the last day of their lives, for example, many of the adolescents reported they would ask forgiveness from parents, friends and relatives for possible suffering they had caused or for not having behaved according to the wishes of the parents. Berkel et al. (2011) highlighted active participation as an important element in the implementation process, often being associated with positive outcomes of an intervention.

Another indicator of the involvement of the adolescents in the intervention was the outcomes from the Letter to a Friend technique, which highlighted, at the end of the intervention, the existence of plans and projects for the future. Their reports indicated mostly specific dreams and goals, compared with vague plans or no plans. Among the future plans more reported by the participants of the intervention, professional and career plans were the most frequent. It is possible that this may be attributed to the fact that the sample, being by convenience, consisted of adolescents inserted in a socio-professional training program. The perception of meaning in life through the establishment of professional and career goals finds support in Frankl (1981/1990, 1978/2005), who states that the experience of values of creation (values linked to action, tasks or work) is a way to find meaning in life. Furthermore, studies show that the perception of future goals is a motivating factor in the search for strategies to achieve them (Río González $\&$ Herrera, 2006) and a protective factor that promotes resilience (McCabe \& Barnett, 2000).

Regarding the social validity, the reports of the participants showed recognition that the themes investigated were important and would help to construct a life project from the reflection and experience of personal values. This perception of relevance of the content of the inter- 
vention is consistent with the outcomes found, corroborating the assumption that socially valid interventions tend to be more effective (Lane \& Beebe-Frankenberger, 2004). Concerning the evaluation of satisfaction with the intervention, from the Emotions Diary, a higher frequency of positive emotions was observed, compared to negative emotions.

The outcomes show that the mean scores of positive emotions increased during the intervention process. The participant satisfaction, although insufficient, can be considered an indicator of a successful intervention (Berkel et al., 2011; Steckler \& Linnan, 2002). The satisfaction of the adolescents with the program could also be measured through the reports during the sessions. For example, the following reports can be cited: "These texts mess with our psychology, but it helps sometimes; we do not stop to think about these things on a daily basis. It seems that it is not important. Now I can think better about what I want to be". Furthermore, these outcomes support the study of Kiang and Fuligni (2010) who found that adolescents who obtained high scores in the presence of meaning also presented higher indices of self-esteem, well-being, academic adjustment and a greater sense of connection to their ethnic group.

Generally, the outcomes of this study indicate evidence supporting the effectiveness of the intervention. When compared to the $\mathrm{CG}$, the $\mathrm{EG}$ showed positive changes in the scores of perceived meaning in life, as well as a reduction of negative affects. These data are consistent with the qualitative data related to the development of life projects at the end of the intervention, which seems to indicate the presence of resources and sources of motivation to achieve the goals established. Furthermore, these outcomes are in line with the successful implementation of the intervention, considering the involvement of the adolescents in the intervention, their comprehension of the procedures, their satisfaction and their perception of the relevance of the intervention (Berkel et al., 2011; Lane \& Beebe-Frankenberger, 2004; Steckler \& Linnan, 2002).

However, the analyzes performed in this study did not allow the extent to which the pro- cess indicators affected the intensity of the outcomes to be established. Evidence from a systematic review of literature on the relationship between the quality of the implementation and the outcomes of prevention programs (Durlak $\&$ DuPree, 2008) showed a positive relationship between the process and the effects of this intervention. However, firm conclusions should await future studies that examine elements of the process as mediators and moderators of the outcomes (Hayes, Laurenceau, \& Cardaciotto, 2008).

The evidence of this study, added to that obtained by Aquino et al. (2011), consistently suggests benefits of the intervention in promoting meaning in life for adolescents. These findings suggest the applicability of Logotherapy in the promotion of actions of mental health and prevention of health problems in adolescence, as in similar work described by Bretones (1998), Leonardi (2011) and Reinhold (2004). This study also presents some additional contributions to the initial study of Aquino et al. (2011), among which, the replication in a new context, the use of multiple measures and the evaluation of the intervention process may be mentioned. In addition to the expansion of the previous studies on this topic, the relevance of these findings for the field of adolescent health can be highlighted. According to the findings of Kiang and Fuligni (2010), adolescents who obtain high scores in the presence of meaning also present higher indices of self-esteem, well-being, academic adjustment and a greater sense of connection to their ethnic group. This becomes especially important for the sample studied and other populations in similar conditions of vulnerability, given the expansion of their protective factors and health potential.

This study is characterized as being an intervention replication study. The replication of a study aims to find outcomes similar to those found previously, being considered a criterion of effectiveness of an intervention (Flay et al., 2005). In this way, some challenges are caused for the researcher, among which is the adaptation - modifications required for the proper functioning of intervention in the new environment - without, however, neglecting 
the fidelity of implementation, that is, without emptying the intervention of its critical components (Berkel et al., 2011). In this study, a more compact version of the intervention was adopted, while its objectives, procedures and core contents were preserved. The format used in this study, with six sessions, proved to be more feasible to implement, compared to the original intervention of 15 sessions (Aquino et al., 2011). The findings of the present study, as the replication of a preventive intervention and its systematic evaluation, indicate the relevance of the sensitive adaptation to the context, without threats to the fidelity, and extend the evidence of effectiveness of national interventions in the prevention and promotion of the mental health of adolescents, a need highlighted by Abreu (2012), still scarce in Brazil.

Despite advances in relation to the initial proposal of Aquino et al. (2011), this study presents some limitations. The main one is the lack of random allocation of participants between the experimental and control groups. Although the CG and EG did not differ significantly from each other in sociodemographic characteristics and the initial scores of the variables studied, the equivalence between them in the pre-test cannot be guarantee. Other important limitations are the sampling by convenience, the lack of a followup and of a qualitative assessment, through the application of the Letter to a Friend, not performed before the intervention or in the CG.

Therefore, it is suggested that future studies amplify the sample, make use of randomized comparison groups, include longitudinal assessments and combine qualitative measures with the quantitative ones. Additionally, care is recommended to reduce the complexity of the intervention in order to facilitate the recruitment of new participants. The format used in this study, with six sessions, proved to be more feasible to implement, compared to the original intervention of 15 sessions (Aquino et al., 2011). Therefore, future studies should consider briefer formats in order to facilitate the adoption by specialized services for adolescents and promote adherence and retention of the participants.

\section{References}

Abreu, S. O. (2012). Prevenção primária em saúde mental no Brasil na perspectiva da literatura e de especialistas da área (Master's thesis, Universidade de Brasília, DF, Brazil). Retrieved from http://repositorio.unb.br/bitstream/10482/11952/1/2012_SamiaAbreuOliveira.pdf

Aquino, T. A. A. (2013). Logoterapia e análise existencial. São Paulo, SP: Paulus.

Aquino, T. A. A (2015). Sentido da vida e valores no contexto da educação: Uma proposta de intervenção à luz do pensamento de Viktor Frankl. São Paulo, SP: Paulinas.

Aquino, T. A. A., Correia, A. P. M., Marques, A. L., C., Souza., C. G., Freitas, H. C. A., \& Dias, P. S., Araújo, W. F. (2009). Atitude religiosa e sentido da vida: Um estudo correlacional. Psicologia: Ciência e Profissão, 29(2), 228243. doi:10.1590/S1414-98932009000200003

Aquino, T. A. A., Damásio, B. F., \& Silva, J. P. (Eds.). (2012). Logoterapia e educação: Fundamentos e prática. São Paulo, SP: Paulinas.

Aquino, T. A. A., Gouveia, V. V., Aguiar, A. A., Pereira, G. A., Fernandes, A. S., Serafim, T. D. B., \& Pontes, A. M. (2015). Questionário de Sentido da Vida: Evidências de sua validade fatorial e consistência interna. Psicologia: Ciência e Profissão, 35(1), 4-19. doi:10.1590/19823703001332012

Aquino, T. A. A., Silva, J. P., Figueiredo, A. T. B., Dourado, E. T. S., \& Farias, C. S. (2011). Avaliação de uma proposta de prevenção ao vazio existencial com adolescentes. Psicologia: Ciência e Profissão, 31, 146-159. doi:10.1590/S141498932011000100013

Arteche, A. X., \& Bandeira, D. R. (2003). Bem-estar subjetivo: Um estudo com adolescentes trabalhadores. Psico-USF, 8(2), 193-201. Retrieved from http://www.scielo.br/pdf/pusf/v8n2/ v8n2a11.pdf

Bardin, L. (1977). Análise de conteúdo. São Paulo, SP: Edições 70.

Berkel, C., Mauricio, A. M., Schoenfelder, E., \& Sandler, I. N. (2011). Putting the pieces together: An integrated model of program implementation. Prevention Science, 12, 23-33. doi:10.1007/ s11121-010-0186-1 
Bonebright, C. A., Clay, D. L., \& Ankenmann, R. D. (2000). The relationship of workaholism of with work life conflict, life satisfaction and purpose in life. Journal of Counseling Psychology, 47, 469-477. doi:10.1037/0022-0167.47.4.469

Brassai, L., Piko, B. F., \& Steger, M. F. (2010). Meaning in life: Is it a protective factor for adolescents' psychological health? International Journal of Behavioral Medicine, 18, 44-51. doi:10.1007/s12529-010-9089-6

Brassai, L., Piko, B. F., \& Steger, M. F. (2012). Existential attitudes and eastern European adolescents' problem and health behaviors: Highlighting the role of the search for meaning in life. The Psychological Record, 62, 719-739.

Bretones, F. (1998). A logoterapia é óbvia: Experiências logoterapêuticas com o homem comum. São Paulo, SP: Paulinas.

Chaves, S. S. S. (2003). Valores como preditores do bem-estar subjetivo (Master's thesis, Universidade Federal da Paraíba, João Pessoa, PB, Brazil). Retrieved from http:/www.vvgouveia.net/ images/Dissertações 1/Chaves_S._S._S._2003. pdf.pdf

Crumbaugh, J., \& Maholick, L. (1964). An experimental study of existentialism: The psychometric approach to Frankl's concept of noogenic neurosis. Journal of Clinical Psychology, 20, 200-207.

Damásio, B. F. (2013). Sentido de vida e bem-estar subjetivo: Interações com esperança, otimismo, autoeficácia e autoestima em diferentes etapas do ciclo vital (Doctoral dissertation, Universidade Federal do Rio Grande do Sul, Porto Alegre, RS, Brazil). Retrieved from http://www. lume.ufrgs.br/handle/10183/80120

Damásio, B. F., Melo, R. L. P., \& Silva, J. P. (2013). Sentido de vida, bem-estar psicológico e qualidade de vida em professores escolares. Paideia (Ribeirão Preto), 23, 73-82. doi:10.1590/198243272354201309

Debats, D. L., Van der Lubbe, P. M., \& Vezeman, F. R. A. (1993). On psychometric properties of theLife Regard Index (LRI): A measure of meaningful life. Personality and Individual Differences, 14, 337-345. doi:10.1016/01918869(93)90132-M

Diener, E., \& Emmons, R. A. (1984). The independence of positive and negative affect. Journal of Personality and Social Psychology, 47(5),
1105-1117. doi:http://dx.doi.org/10.1037/00223514.47.5.1105

Doğana, T., Sapmaz, F., Telb, F. D., Sapmaz, S., $\&$ Temizelc, S. (2012). Meaning in life and subjective well-being among Turkish university students. Procedia - Social and Behavioral Sciences, 55, 612-617. doi:10.1016/j.sbspro.2012.09.543

Duarte, C. Z. C. G. (2015). Adolescência e sentido de vida. Curitiba, PR: CRV.

Durlak, J. A., \& DuPree, E. P. (2008). Implementation matters: A review of research on the influence of implementation on program outcomes and the factors affecting implementation. American Journal of Community Psychology, 41, 327-350.

Flay, B. R., Biglan, A., Boruch, R., Castro, F. G., Gottfredson, D., Kellam, S., ...Ji, P. (2005). Standards of evidence: Criteria for efficacy, effectiveness and dissemination. Prevention Science, 6, 151-175. doi:10.1007/s11121-0055553-y

Frankl, V. E. (1990). A questão do sentido em psicoterapia (J. Mitre, Trans.). Campinas, SP: Papirus. (Original work published 1981)

Frankl, V. E. (2005). Um sentido para a vida. Psicoterapia e humanismo (V. H. S. Lapental, Trans.). Aparecida, SP: Ideias e Letras. (Original work published 1978)

Frankl, V. E. (2011). Em busca de sentido: Um psicólogo no campo de concentração (W. O. Schlupp \& C. C. Aveline, Trans.). São Leopoldo, RS: Sinodal. (Original work published 1946)

Gomes, E. S. (2009). Evidencias teóricas y empíricas entre la psicologia positiva de Seligman y la psicologia humanista-existencial de Frankl (Unpublished doctoral dissertation, Universidad Pontificia de Salamanca, Spain).

Haditabar, H., Far, N. S., \& Amani, Z. (2013). Effectiveness of logotherapy concepts training in increasing the quality of life among students. International Journal of Psychology and Behavioral Research, 2(4), 223-230.

Hayes, A. M., Laurenceau, J., \& Cardaciotto, L. (2008). Methods for capturing process of change. In A. M. Nezu \& C. M. Nezu (Eds.), Evidence-based outcome research. A practical guide to conducting randomized controlled trials for psychosocial interventions (pp. 335-358). New York: Oxford University Press. 
Huebner, E., \& Dew, T. (1996). The inter-relationships of positive affect, negative affect and life satisfaction in an adolescent sample. Social Indicators Research, 38, 129-137. doi:10.1007/ BF00300455

Lane, K. L., \& Beebe-Frankenberger, M. (2004). Social validity: Goals, procedures, and outcomes. In K. L. Lane \& M. Beebe-Frankenberger (Eds.), School-based interventions: The tools you need to succeed (pp. 85-127). Boston, MA: Pearson Education.

Kiang, L., \& Fuligni, A. J. (2010). Meaning in life as a mediator of ethnic identity and adjustment among adolescents from Latin, Asian, and European American backgrounds. Journal of Youth and Adolescence, 39, 1253-1264. doi:10.1007/ s10964-009-9475-z

Kang, K., Im, J., Kim, H., Kim, S., Song, M., \& Sim, S. (2009). The effect of logotherapy on the suffering, finding meaning, and spiritual well-being of adolescents with terminal cancer. Journal of Korean Academy of Nursing, 15(2), 136-144. doi:10.4094/jkachn.2009.15.2.136

Kazdin, A. E. (2010). Research design in Clinical Psychology. Boston, MA: Allyn e Bacon.

Leonardi, J. (2011). Logomúsica: A criação de um novo approach musicoterápico como veículo na promoção de saúde mental (Doctoral dissertation, Universidade de São Paulo, SP, Brazil). Retrieved from http://www.teses.usp.br/teses/ disponiveis/22/22131/tde-31102011-084343/ en.php

Lukas, E. (1992). Assistência logoterapêutica: Transição para uma psicologia humanizada. Petrópolis, RJ: Vozes.

Malta, D. C., Mascarenhas, M. D. M., Porto, D. L., Duarte, E. A., Sardinha, L. M., Barreto, S. M., \& Morais, O. L., Neto. (2011). Prevalência do consumo de álcool e drogas entre adolescentes: Análise dos dados da Pesquisa Nacional de Saúde Escolar. Revista Brasileira de Epidemiologia, 14(1), 136-146. doi:10.1590/S1415790X2011000500014

McCabe, K., \& Barnett, D. (2000). First comes work, then comes marriage: Future orientation among African American young adolescents. Family Relations, 49, 63-70. doi:10.1111/j.17413729.2000.00063.x

Nascimento, M. O., \& Avallone, D. M. (2013). Prevalência do uso de drogas entre adolescentes nos diferentes turnos escolares. Adolescência \& Saúde, 10(4) 41-49. doi:10.1590/S003489102001000200008

National Youth Secretariat. (2014). Agenda juventude Brasil. Brasília, DF: Author.

Reinhold, H. H. (2004). O sentido da vida: Prevenção do stress e burnout do professor (Doctoral dissertation, Pontifícia Universidade Católica de Campinas, SP, Brazil). Retrieved from www. bibliotecadigital.puc-campinas.edu.br/tde_busca/arquivo.php?codArquivo $=250$

Río-González, A. M., \& Herrera, A. N. (2006). Desarrollo de un instrumento para evaluar perspectiva de tempo futuro em adolescentes. Avances en Medición, 4, 47-60. Retrieved from http://www.humanas.unal.edu.co/psicometria/ files/7913/7036/4860/Desarrollo De Un Instrumento_Para_Evaluar_Perspectiva_De Tiempo Futuro En Adolescentes.pdf

Ryff, C., \& Keyes, C. (1995). The structure of psychological well-being revisited. Journal of Personality and Social Psychology, 69(4), 719-727. doi:10.1037/0022-3514.69.4.719

Steckler, A., \& Linnan, L. (2002). Process evaluation for public health interventions and research. An overview. In A. Steckler \& L. Linnan (Eds.), Process evaluation for public health interventions and research (pp. 1-21). San Francisco, CA: Jossey-Bass.

Steger, M. F. (2009). Meaning in life. In S. J. Lopez (Ed.), Oxford handbook of positive psychology ( $2^{\text {nd }}$ ed., pp. 679-687). Oxford, UK: Oxford University Press.

Steger, F. M., Frazier, P., Oishi, S., \& Kaler, M. (2006). The meaning in Life Questionnaire: Assessing the presence of and search for meaning in life. Journal of Counseling Psychology, 53, 80-93. doi:10.1037/0022-0167.53.1.80

Waiselfisz, J. J. (2014). Mapa da violência 2014: Os jovens do Brasil. Brasília, DF: Flacso Brasil. 